\title{
INTEGRATED ANALYSIS AND MAPPING OF ARIDITY OVER GREEK AREAS WITH DIFFERENT CLIMATE CONDITIONS
}

\author{
PAPARRIZOS S. ${ }^{1}$ \\ MARIS F. ${ }^{2}$ \\ MATZARAKIS A. ${ }^{3}$
}

\author{
${ }^{1}$ Faculty of Environment and Natural Resources \\ Albert-Ludwigs-University Freiburg \\ D-79085 Freiburg, Germany \\ ${ }^{2}$ Department of Forestry and Management of the \\ Environment and Natural Resources \\ Democritus University of Thrace \\ Pantazidou str. 192, GR-68200 Orestiada, Greece \\ ${ }^{3}$ Research Center Human-Biometeorology, German Weather Service \\ Stefan-Meier-Str. 4, D=79104 Freiburg, Germany
}

Received: 01/10/2015

Accepted: 04/12/2015

Available online: 19/01/2016 *to whom all correspondence should be addressed: e-mail: spyridon.paparrizos@meteo.uni-freiburg.de

\section{ABSTRACT}

Assessment of aridity conditions prevailing in a certain area is essential for the research on climate and climate change. Greece is characterized by a variety of climatic conditions such as drought conditions or flooding phenomena. The current study focuses on three selected areas within Greece that present different climatic characteristics due to their location and aims to analyze and compare the aridity conditions prevailing in these areas. Aridity conditions were estimated using the Aridity Index (Al). MannKendall test was applied to investigate possible trends. Spatial distribution of aridity conditions was performed using multi-linear regression techniques and Kriging method within ArcGIS 10.2.1.

The results indicated that the study areas face humid conditions, mostly due to the existence of high altitudes. Furthermore, the various climatic conditions are responsible for differentiations in seasonal analysis regarding the aridity conditions. The study areas related to the Mediterranean climate resulted more heterogeneous conditions compared with areas affected by the continental climate. Nevertheless, the created aridity spatial maps of trend analysis presented with differentiations, especially in the mountainous areas were an extreme downward trend is appeared. For the southern investigated area in Crete Island characterized purely by Mediterranean climate, the results were more moderate in terms of aridity conditions.

Keywords: Aridity, Aridity Index, multi-linear regression, Ordinary Kriging, Greece

\section{Introduction}

Climate change is the greatest human challenge facing the world, as negative effects, such as flooding phenomena, heat waves, forest fires and droughts have started becoming very severe (Hillel and Rosenzweig, 2002). Human activities have been affected by this change and they will continue influencing in the future (IPCC, 2014). According to previous publications from the Intergovernmental Panel on Climate Change (IPCC) uncertainties in climate change impacts on water resources, droughts and floods arise for various reasons such as different scenarios of economic development, greenhouse emissions, 
climate and hydrological modeling (IPCC, 2007). The latest IPCC publications mask the importance of the regional changes and refer that these regional to global-scale projections of drought remain relatively uncertain compared to other aspects of the water cycle (IPCC, 2014).

Aridity is a term that most people conceptually understand, and it evokes images of dry, desert lands with sparse natural surface-water bodies and rainfall, and commonly only scant vegetation, which is adapted to a paucity of water (Maliva and Missimer, 2012). Aridity, as defined by the shortage of moisture, is essentially a climatic phenomenon that is based on average climatic conditions over a region (Agnew and Anderson, 1992). A fundamental distinction exists between aridity, which is a long-term climatic phenomenon and droughts, which are a temporary phenomenon (water deficit).

Numerous numerical indices have been proposed to quantify the degree of dryness of a climate at a given location, and thus define climatic zones. De Martonne aridity index (1926) is an aridity-humidity index that uses precipitation and temperature as inputs and can be applied locally. Thornthwaite classification (1948) is another major index and it is calculated using water deficiency and water need as inputs. Additionally, the Pinna Combinative index (IP) (Zampakas, 1992) which also uses precipitation and air temperature as inputs constitutes an index mainly applied in areas where irrigation is necessary since it takes into account the precipitation and air temperature of the driest month. Finally, Aridity Index (AI) which is delivered from the United Nations Environment Program (UNEP, 1992), constitutes a numerical indicator of the degree of dryness of the climate at a given location and uses precipitation and potential evapotranspiration data. The chosen proxy (e.g. precipitation, evapotranspiration, soil moisture or stream flow) and time scale can strongly affect the ranking of aridity classification over a certain area (Sheffield et al., 2009).

Aridity and thus droughts impacts concern a variety of sectors of economy, environment and society of the affected area (Chen et al., 2001; Wang et al., 2010). The socio-economic impacts of environments may arise from the interaction between natural conditions and human factors such as changes in land use, land cover and the demand and use of water. Excessive water withdrawals can exacerbate the impact of drought and aridity classification (Wang, 2005; Holman, 2006).

Climate uncertainties results from drought phenomena is one of the major threats in contemporary water resources management (Saravi et al., 2009). Water consumption is increasing in semi-arid rural regions around the world, mainly due to developing agricultural activities. Moreover, the rapid growth of world population and uneven distribution of resources have served to escalate both the frequency and severity of natural hazards and disasters, especially in semi-arid regions (Dalezios and Bartzokas, 1995). Specifically, Greece belongs to a region in south-eastern Europe in which the use of water resources is mandatory for agriculture. Thus aridity conditions and droughts as climatic extremes are more critical for agriculture than the average conditions (Dalezios et al., 2000; Tigkas et al., 2012).

The under investigation study areas are Ardas River basin in north-eastern Greece, Sperchios River basin in Central Greece and Geropotamos River basin in Crete Island in southern Greece. The reason for the selection of the specific study areas lies in the fact that the agriculture is the main production and economic activity. A significant part of the local population is employed fully or partly in the primary sector (agriculture and livestock). Due to this fact, most of the local population used the water from the torrential streams for irrigation. Irrigation plays an important role, due to the reduced amount of water availability from rainfalls and the farmer's inability to "buy" water. Farming and manufacturing activities based on the agricultural activity, as well as other activities of the primary and secondary sector production are a pressing need for a research that will provide adapting systems and information regarding to availability of water and drought conditions (Paparrizos et al., 2015a).

The results of the current study will provide the opportunity to the farmers, residents and all the stakeholders to understand the climate conditions prevailing in their area regarding the aridity conditions and adjust their systems in order to come up with future conditions. This contributes in the development of the agricultural production for the local population related with agricultural activities or, for these who have in mind to occupy with the agriculture sector. 
The climatic conditions in the certain areas vary as the Geropotamos River basin in Crete Island is affected by the Mediterranean climate conditions, while the Sperchios River basin in Central Greece faces the same conditions with some minor variation on the rivers' springs in the mountainous area where milder conditions appear. From the other hand, the Ardas River basin in northeastern Greece is affected by the continental climate and presents different climatic conditions. Additionally, the study will also focus to the role that topography plays in the creation of these conditions. Finally, the current research will help to understand the response of the aridity conditions respecting the climate conditions of each area, in order to plan, implement and manage the water resources and water availability that will lead to a sustainable development of the agriculture and the environment.

The current study focuses on the estimation and spatial distribution of the aridity conditions using the Aridity Index (AI) prevailing in 3 selected areas in Greece. The equation of Aridity Index used precipitation and potential evapotranspiration data in order to be applied. Spatial distribution of the drought phenomena was conducted combing a multi-linear regression technique that used all the available parameters affecting precipitation and PET and the interpolation method of ordinary Kriging through ArcGIS 10.2.1 program.

\section{Method \& materials}

\subsection{Study areas}

The study areas are located in Greece. The Ardas River basin (Manolas et al., 2009; Paparrizos et al., 2016) is located in the north-eastern part of Greece (a big part of the basin belongs to Bulgaria - mostly the mountainous area of the basin) with an area of $5681.3 \mathrm{~km}^{2}$. The mean annual precipitation is $839.8 \mathrm{~mm}$ while the mean annual $\mathrm{T}_{\text {mean }}$ is $10.5^{\circ} \mathrm{C}$. In the Ardas River basin various climate types exist, but the basin is mainly characterized by humid continental climate conditions (Peel et al., 2007). Sperchios River basin (Paparrizos et al., 2014; 2015a; 2015b) with an area of $1727.7 \mathrm{~km}^{2}$ is located in Central Greece and it faces Mediterranean conditions with mean annual precipitation of $771.1 \mathrm{~mm}$ and mean annual $\mathrm{T}_{\text {mean }}$ of $16.6^{\circ} \mathrm{C}$. The $3^{\text {rd }}$ area is Geropotamos River basin (Stobbelaar 2000; Matzarakis and Nastos 2011; Bleta et al. 2014), located in South Greece in Crete Island. It has an area of $651.6 \mathrm{~km}^{2}$, mean annual precipitation of $846.7 \mathrm{~mm}$ and mean annual $\mathrm{T}_{\text {mean }} 17.2^{\circ} \mathrm{C}$.

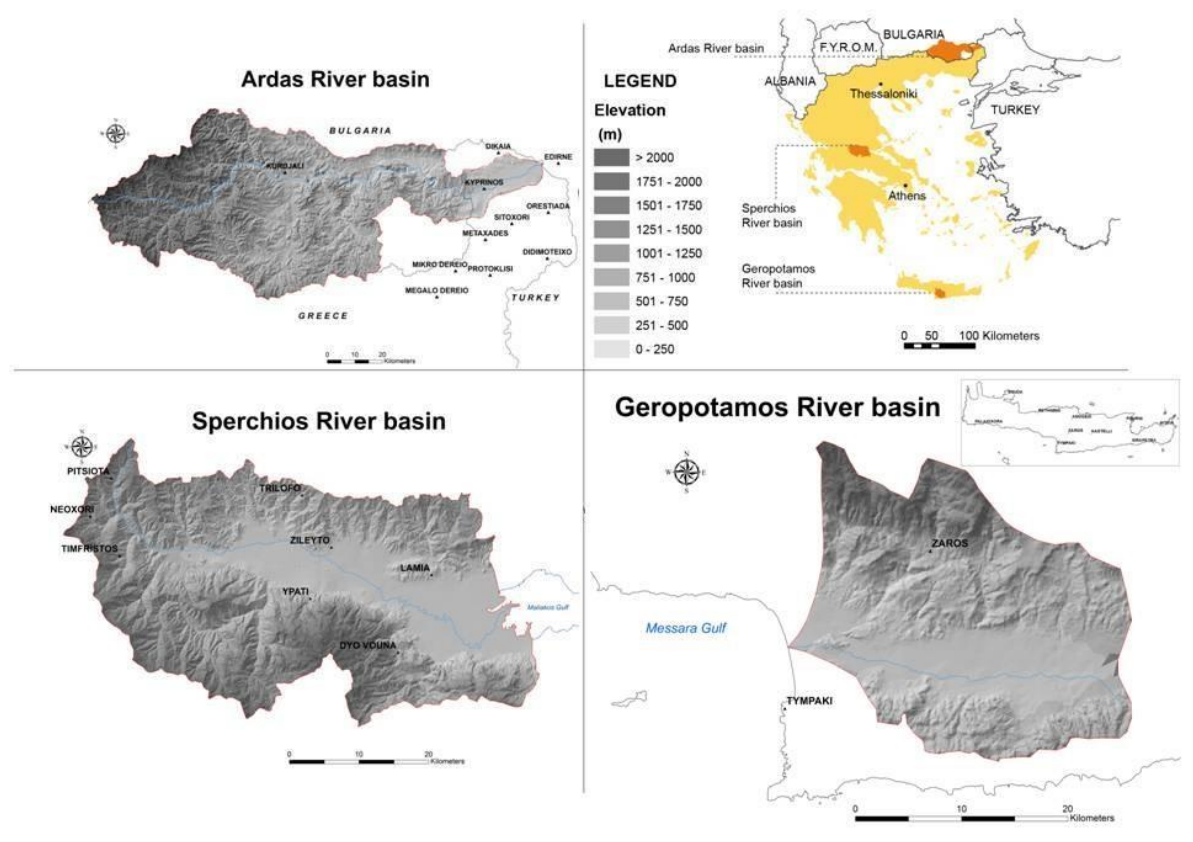

Figure 1. Location of the study areas in Greece 
Table 1 presents the local population that is employed in the primary section or are related with agricultural activities, while Figure 1 shows the general location, the meteorological stations and the characteristics of the study areas.

Table 1. Local population related with the primary section

\begin{tabular}{ccccc}
\hline Study area & Region & Region Population & $\begin{array}{c}\text { People occupied in the } \\
\text { primary section }\end{array}$ & $\begin{array}{c}\text { Percentage } \\
\text { (\%) }\end{array}$ \\
\hline Ardas River basin & Evros & 149.354 & 37.560 & 25.1 \\
\hline Sperchios River basin & Ftiotida & 169.542 & 52.426 & 30.9 \\
\hline Geropotamos River basin & Irakleion & 304.270 & 116.251 & 38.2 \\
\hline
\end{tabular}

\subsection{Climate Dato}

Daily values of meteorological data obtained from stations within or adjacent to the study areas as can be seen in Figure 1, derived from the Hellenic Meteorological Service (HNMS) and OGIMET ${ }^{1}$ were used in the study. The characteristics of the stations can be found in Table 2 .

Table 2. Meteorological stations and their characteristics

\begin{tabular}{|c|c|c|c|c|c|}
\hline Study area & Stations & Lat. & Long. & Elevation (m) & Years \\
\hline \multirow{11}{*}{ Ardas River basin } & Dikaia & 41.7 & 26.3 & 90.7 & \multirow{11}{*}{$1985-2000$} \\
\hline & Kuprinos & 41.58 & 26.23 & 51.2 & \\
\hline & Sitoxori & 41.46 & 26.35 & 112.4 & \\
\hline & Mikr. Dereio & 41.31 & 26.1 & 129.2 & \\
\hline & Meg. Dereio & 41.23 & 26.01 & 401.4 & \\
\hline & Protoklisi & 41.3 & 26.25 & 55.1 & \\
\hline & Didimoteixo & 41.35 & 26.5 & 48.4 & \\
\hline & Metaxades & 41.41 & 26.23 & 129 & \\
\hline & Orestiada & 41.5 & 26.51 & 39.2 & \\
\hline & Edirne & 41.66 & 26.56 & 50 & \\
\hline & Kurdjali & 41.65 & 25.36 & 273.3 & \\
\hline \multirow{8}{*}{$\begin{array}{c}\text { Sperchios River } \\
\text { basin }\end{array}$} & Neoxori & 38.96 & 21.86 & 800 & \multirow{8}{*}{$1981-2000$} \\
\hline & Pitsiota & 39.01 & 21.9 & 800 & \\
\hline & Zileuto & 38.93 & 22.26 & 120 & \\
\hline & Lamia & 38.9 & 22.43 & 144 & \\
\hline & Trilofos & 39 & 22.21 & 580 & \\
\hline & Timfristos & 38.91 & 21.91 & 850 & \\
\hline & Ypati & 38.86 & 22.23 & 286 & \\
\hline & Duo Vouna & 38.79 & 22.38 & 460 & \\
\hline \multirow{11}{*}{$\begin{array}{c}\text { Geropotamos } \\
\text { River basin }\end{array}$} & Souda & 35.54 & 24.1 & 106.4 & \multirow{11}{*}{$1981-2000$} \\
\hline & Irakleio & 35.32 & 25.17 & 68.3 & \\
\hline & lerapetra & 35.01 & 25.72 & 24.2 & \\
\hline & Siteia & 35.19 & 26.09 & 25 & \\
\hline & Rethimno & 35.34 & 24.5 & 118 & \\
\hline & Tympaki & 34.99 & 24.74 & 33.7 & \\
\hline & Palaioxora & 35.23 & 23.68 & 25 & \\
\hline & Anogeia & 35.28 & 24.95 & 823.7 & \\
\hline & Fourni & 35.25 & 25.66 & 500 & \\
\hline & Kastelli & 35.12 & 25.2 & 350 & \\
\hline & Zaros & 35.13 & 24.9 & 322 & \\
\hline
\end{tabular}

\footnotetext{
${ }^{1}$ www.ogimet.com
} 
Since Greece is an area characterized by diverse climate conditions, even in areas very close to each other, due to the harsh topography and geomorphology, several stations nearby the study areas were also used. This was intended both to the fact that any deficiencies created by the different micro-climates and the multivarious background could be eliminated since the current research is focused on the mesoscale and also to provide the multi-linear regression with as much data as possible in order to validate its sufficiency and perform the spatial interpolation of the Aridity Index. Additionally, the existence of limited data in Greece which is a problem that the researcher is called to overcome also contributed towards the selection of the stations that will be used in the current study. As there were no available common meteorological data series for the study areas, a homogeneity test was performed (Dingman, 1994; 2002) followed by a statistical correlation test, the t-test (Snedecor and Cochran, 1989; Haan, 2002) in order to correlate the existing values and determine the reference periods that will be adopted in the current study. Finally the determined reference periods were 1981-2000 for the Sperchios and the Geropotamos River basins and 1985-2000 for the Ardas River basin.

\subsection{Aridity Index}

In the current study, Aridity Index (Al) was selected in order to estimate the aridity conditions. A number of aridity indices have been proposed; these indicators serve to identify, locate or delimit regions that suffer from a deficit of water availability, a condition that can severely affect the effective use of the land for such activities as agriculture or stock-farming. The equation (Eq. 1) for the estimation of the Aridity Index (AI) is (UNEP, 1992):

$$
\mathrm{Al}=\frac{\mathrm{P}}{\mathrm{PET}}
$$

Where $P$ is the average annual precipitation $(\mathrm{mm})$ and PET is the average annual potential evapotranspiration $(\mathrm{mm})$. The boundaries that define various degrees of aridity are involved as shown in Table 3 (FAO, 1993).

Table 3. Classification of Aridity Index categories

\begin{tabular}{cc}
\hline Classification & Aridity Index (AI) \\
\hline Hyper-arid & $\mathrm{Al} \leq 0.05$ \\
\hline Arid & $0.05 \leq \mathrm{Al}<0.20$ \\
\hline Semi-arid & $0.20 \leq \mathrm{Al}<0.50$ \\
\hline Dry sub-humid & $0.50 \leq \mathrm{Al}<0.65$ \\
\hline Sub-humid & $0.65 \leq \mathrm{Al}<0.80$ \\
\hline Humid & $0.80 \leq \mathrm{Al}<1.5$ \\
\hline Very humid & $1.5 \leq \mathrm{Al}$ \\
\hline
\end{tabular}

\subsection{EmPEst software for PET estimation}

PET was estimated with the use of EmPEst software (Xystrakis and Kostinakis, 2010; Kostinakis et al., 2011). EmPEst (empirical potential evapotranspiration estimation) is a simple software that can estimate daily PET by means of 14 different empirical equations. These equations include the PET $\mathrm{ASCE}_{\mathrm{A}}$ equation (ASCE Task Committee, 2005), the approaches of Hargreaves (Allen et al., 1998), McGuiness (Oudin et al., 2005), Jensen (Jensen and Haise, 1963), Hansen (Xu and Singh, 2002), Caprio (Caprio, 1974), Romanenko (Oudin et al., 2005), Turc (Lu et al., 2005), Makkink (Rosenberry et al., 2004), de Bruin (Rosenberry et al., 2004), McCloud (Jacobs and Satti, 2001; Irmak et al., 2003) and three versions of Hamons approach (Kostinakis et al., 2011; Xystrakis and Matzarakis, 2011). Table 4 presents the equations and the input variables that each equation uses in order to calculate PET. The input parameters of these equations include: $\mathrm{T}_{\text {mean }}=$ Mean air temperature $\left({ }^{\circ} \mathrm{C}\right) ; \mathrm{T}_{\min }=$ Minimum air temperature $\left({ }^{\circ} \mathrm{C}\right)$; $\mathrm{T}_{\max }=$ Maximum air temperature $\left({ }^{\circ} \mathrm{C}\right) ; \mathrm{T}_{\text {dew }}=$ dew point temperature $\left({ }^{\circ} \mathrm{C}\right) ; \mathrm{RH}=$ Relative Humidity $(\%)$; Wind speed $\left(\mathrm{m} \mathrm{s}^{-1}\right) ; \mathrm{DL}=$ Day Length (Hours); $\mathrm{R}_{\mathrm{s}}=\mathrm{Global}$ (total) radiation $\left(\mathrm{MJ} \mathrm{m}^{-2}\right) ; \mathrm{R}_{\mathrm{a}}=$ Extraterrestrial radiation $\left(\mathrm{MJ} \mathrm{m}{ }^{-2}\right) ; R_{n}=$ Net radiation ( $\left.M J ~^{-2}\right)$. The PET values that were used each time in the Aridity Index equation (Eq. 1) were the mean average values from these 14 equations. 
Table 4. Input data requirements for the PET equations used by EmPEst software

\begin{tabular}{|c|c|c|c|c|c|c|c|c|c|c|}
\hline $\begin{array}{c}\text { PET } \\
\text { Equation }\end{array}$ & $\begin{array}{c}T_{\text {mean }} \\
\left({ }^{\circ} \mathrm{C}\right)\end{array}$ & $\begin{array}{l}T_{\min } \\
\left({ }^{\circ} \mathrm{C}\right) \\
\end{array}$ & $\begin{array}{l}T_{\max } \\
\left({ }^{\circ} \mathrm{C}\right) \\
\end{array}$ & $\begin{array}{l}T_{\text {dew }} \\
\left({ }^{\circ} \mathrm{C}\right) \\
\end{array}$ & $\begin{array}{c}\text { RH } \\
\% \\
\end{array}$ & $\begin{array}{c}\begin{array}{c}\text { Wind } \\
\text { speed }\end{array} \\
\mathrm{m} / \mathrm{s} \\
\end{array}$ & $\begin{array}{l}\text { DL } \\
\text { (h) }\end{array}$ & $\begin{array}{c}R_{\mathrm{s}} \\
\mathrm{MJ} \mathrm{m}^{-2}\end{array}$ & $\begin{array}{c}R_{a} \\
M J ~^{-2}\end{array}$ & $\begin{array}{c}R_{n} \\
M J m^{-2}\end{array}$ \\
\hline PET $_{\text {ASCE }}$ & $\checkmark$ & $\checkmark$ & $\checkmark$ & $\checkmark$ & & $\checkmark$ & & & & $\checkmark$ \\
\hline PET $_{\text {Cap }}$ & $\checkmark$ & & & & & & & $\checkmark$ & & \\
\hline $\mathrm{PET}_{\mathrm{deB}}$ & $\checkmark$ & & & & & & & & & $\checkmark$ \\
\hline $\mathbf{P E T}_{\text {Ham1 }}$ & $\checkmark$ & $\checkmark$ & $\checkmark$ & & & & $\checkmark$ & & & \\
\hline PET $_{\text {Ham2 }}$ & $\checkmark$ & & & & & & $\checkmark$ & & & \\
\hline PET $_{\text {Ham3 }}$ & $\checkmark$ & $\checkmark$ & $\checkmark$ & & & & $\checkmark$ & & & \\
\hline $\mathbf{P E T}_{\text {Han }}$ & $\checkmark$ & & & & & & & $\checkmark$ & & \\
\hline PET $_{\text {Har }}$ & $\checkmark$ & $\checkmark$ & $\checkmark$ & & & & & & $\checkmark$ & \\
\hline $\mathrm{PET}_{\text {Jen }}$ & $\checkmark$ & & & & & & & $\checkmark$ & & \\
\hline PET $_{\text {Mak }}$ & $\checkmark$ & & & & & & & $\checkmark$ & & \\
\hline PET $_{\text {McC }}$ & $\checkmark$ & & & & & & & & & \\
\hline PET $_{\text {McG }}$ & $\checkmark$ & & & & & & & & $\checkmark$ & \\
\hline PET $_{\text {Rom }}$ & $\checkmark$ & $\checkmark$ & $\checkmark$ & $\checkmark$ & & & & & & \\
\hline $\mathbf{P E T}_{\text {Tur }}$ & $\checkmark$ & & & & $\checkmark$ & & & & & \\
\hline
\end{tabular}

\subsection{Multi-linear regression, spatial analysis and mapping of aridity}

In the current study the combination of dynamical and statistical downscaling approach was performed in order to downscale and perform the spatial interpolation of the Aridity Index. The methodology applied to the interpolation from irregularly distributed surface station data at coordinates $x_{i}, y_{i}, z_{i}$ (where $x_{i}=$ longitude, $y_{i}=$ latitude and $z_{i}=$ altitude from mean sea level of the $i$ station) to surface gridded points $X_{j}$, $Y_{j}, Z_{j}$ (where $X_{j}=$ longitude, $Y_{j}=$ latitude and $Z_{j}=$ altitude from mean sea level of the $j$ grid) was based on the Ordinary (spherical variogram) Kriging with the procedure of interpolation for geographical information systems (Oliver and Webster, 1990) through ArcGIS 10.2.1 program.

As indicated above, the coefficients that contribute to the application of the Aridity Index are precipitation and potential evapotranspiration. While mapping precipitation and PET in a certain area, several factors need to be taken into account that greatly affect their distribution. These can be separated to physical factors that affect the type, occurrence, and amount of precipitation and PET and environmental factors that affect their composition. In this certain case, the following available factors were take into account: latitude, longitude, presence of mountains and their elevation, slope, prevalent wind speed, distance from a body of water, air temperature, etc.

In order to include all these factors that affect precipitation and PET in the interpolation procedure, several multi-linear regression techniques were performed including the meteorological stations of each area. For each point station of every study area that is mentioned on Table 2, the average annual precipitation (through the rainfall stations) and PET values (through the meteorological stations) were occurred, and Al thus was calculated. Afterwards, the Al values were used as the depended variables, while latitude, longitude, presence of mountains and their elevation, slope, prevalent wind speed, distance from a body of water, temperature, etc.) that affect precipitation and PET were used as independent variables in order for the multi-linear regression to be performed. That constitutes the dynamical approach and downscaling technique.

Additionally, the same procedure was followed for every station and study area and an equation (Eq. 2) was created which has the following form:

$x=b_{0}+b_{1} h+b_{2} s \mid p+b_{3} X+b_{4} Y+b_{5}$ temp $+b_{6} W S+b_{7}$ DistWat

Where $x$ represents the dependent variable at a certain point (Aridity Index value); $b_{0}$ is constant; $b_{1} \ldots b_{7}$ represent the coefficients obtained for each independent variable, $h$ represent the variable of the altitude 
$(\mathrm{m})$, slp is slope $(\%), \mathrm{X}$ is longitude $\left({ }^{\circ}\right), \mathrm{Y}$ is latitude $\left({ }^{0}\right)$, temp is mean air temperature $\left({ }^{0} \mathrm{C}\right)$, WS is wind speed $\left(\mathrm{m} \mathrm{s}^{-1}\right)$ and DistWat is the distance form a water body (sea or lake).

Subsequently, through ArcGIS 10.2.1, in order to perform the Ordinary Kriging analysis and the coupling of the dynamical with the statistical downscaling approach, automatic points $(x)$ within the basin were created within a $1 \times 1 \mathrm{~km}$ resolution grid. Through the multi-linear regression equations that were occurred, each point within the grid of every study area was given an Al value that was occurred by feeding Eq. 2 every time with different values from the independent variables. This constitutes the statistical approach of the downscaling technique that was performed in the current study. The $b_{1} \ldots b_{7}$ values that occurred from each multi-linear regression are constant in every individual equation. Since each point $(x)$ in the grid is unique, the results of the equation are affected every time by the unique independent variables of the point.

This coupling of dynamical and statistical downscaling constitutes an innovation that can be used when the researcher is called to operate on a regional or local scale and produce detailed and not coarse results. Attempts towards this direction have also been performed from Matzarakis et al., (2007); Gouvas et al., (2009); Maris et al., (2013); Feidas et al. (2014) and Paparrizos et al., (2015b; 2016).

\subsection{Mann-Kendall trend analysis}

Trend analysis was performed using the Mann-Kendall test for the years 1981-2100 for the Sperchios and Geropotamos River basins, and for the period 1985-2100 for the Ardas River basin. The Mann-Kendall test (Kendall, 1938; Mann, 1945; Kendall and Stuart, 1969; Kendall, 1975) is a statistical control method, suitable for cases where the trend may be assumed to be monotonic and thus no seasonal or other cycle is present in the data. The presence of a statistically significant trend is evaluated using the $Z$ value. A positive (negative) value of $Z$ indicates an upward (downward) trend. The statistic $Z$ has a normal distribution (Salmi et al., 2002).

\section{Results and discussion}

Table 5 presents the average results for total Aridity Index (AI) estimation, seasonal analysis and trend for the selected study areas.

Table 5. Aridity index analysis results for the selected Greek areas

\begin{tabular}{ccccccc}
\hline Study area & Al Analysis & Winter & Spring & Summer & Autumn & Drought Trend (Z values) \\
\hline Ardas & 0.94 & 1.31 & 0.68 & 0.25 & 1.05 & -0.97 \\
\hline Sperchios & 0.93 & 1.80 & 0.65 & 0.24 & 2.11 & 0.04 \\
\hline Geropotamos & 1.09 & 1.72 & 0.41 & 0.14 & 1.61 & -0.64 \\
\hline
\end{tabular}

Note: mean values

As shown in Table 5, the total analysis of the Aridity Index indicated that all the examined areas face humid conditions during the year. The complex topography with the presence of mountainous areas with high and moderate altitudes validates the results.

However, at this point, special attention needs to be given firstly to Geropotamos River basin. Geropotamos River basin is characterized by Mediterranean climate with the climate type (Csa) according to Köppen-Geiger classification (Peel et al., 2007).

Total aridity index analysis resulted an $\mathrm{Al}=1.09$, which is the highest among the examined areas, although it is located in the southern part of the three study areas and constitutes a part of Crete Island which, through the examined literature above is an Island that faces drought conditions. The under examination study area is characterized by the presence of Mount Psiloritis $(2.456 \mathrm{~m})$, which is the highest mountain of Crete Island. Mount Psiloritis is dominated by abrupt slopes, a phenomenon that exists in the whole territory of Crete Island. Additionally, the Geropotamos River basin is generally a basin with 'small' distances from the watershed limits to the coast line (which is the mouth of the water basin), especially in the northwest part where Mount Psiloritis lies. 
Seasonal aridity index analysis in the Geropotamos River basin follows a natural distribution regarding the climate classification in the certain area, and winter is the most humid season, followed by autumn, spring and summer, respectively. The winter and autumn seasons face humid conditions, while spring faces semi-arid conditions. Summer season faces arid conditions with an $\mathrm{Al}=0.14$. The total analysis of the $\mathrm{Al}$ also indicated that the trend results (and as a result the drought conditions) follow a downward trend.

Concerning the Ardas River basin, the total analysis of the aridity index indicated that the conditions are humid with an Al $=0.94$. The climate classification varies and continental conditions (Dfb) appear in the northwest side of the basin, temperate $(\mathrm{Cfb})$ and humid sub-tropical ( $\mathrm{Cfa}$ ) conditions in the rest of the basin. Due to this classification, seasonal analysis indicated that winter and autumn seasons face humid conditions, spring sub-humid and summer semi-arid conditions. At this case, the trend analysis showed a downward trend ( $Z$ value $=-0.96$ ), which is considered very significant as, according to the analysis, the aridity conditions are reduced.

Respecting the Sperchios River basin, the Aridity Index is on the same level as the Ardas River basin, with $\mathrm{Al}=0.93$. Nevertheless, as shown from Figure 3 below, in some parts of the water basin, arid-conditions appeared. Sperchios River basin has a Mediterranean climate (Csa). Areas with this type of climate receive almost all of their precipitation during the winter, autumn and spring seasons and may go anywhere from 4 to 6 months during the summer without having any significant precipitation (Peel et al., 2007). This is verified by the fact that spring and summer seasons face dry sub-humid and semi-arid conditions respectively, while autumn is the season that faces the most humid conditions of the year. Implementation of the Mann-Kendal test, a $Z$ value of 0.04 was estimated, which shows a minor upward trend of the drought conditions prevailing in the Sperchios River basin.

Subsequently, Figures 2-4 depict the spatial interpolation of the aridity index analysis (total analysis, seasonal analysis and trend) for the selected study areas.

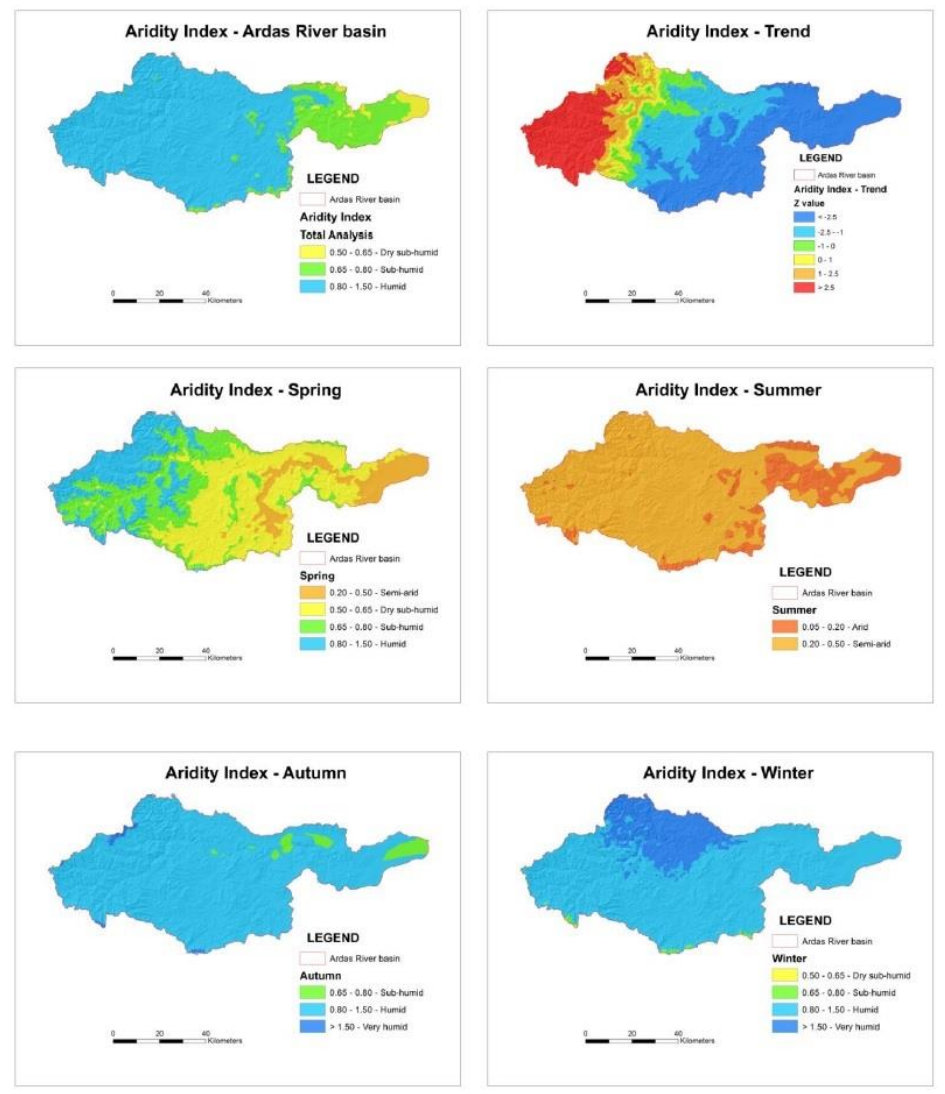

Figure 2. Aridity Index analysis maps for Ardas River basin a) Total Analysis b) Trend c) Spring d) Summer e) Autumn f) Winter 

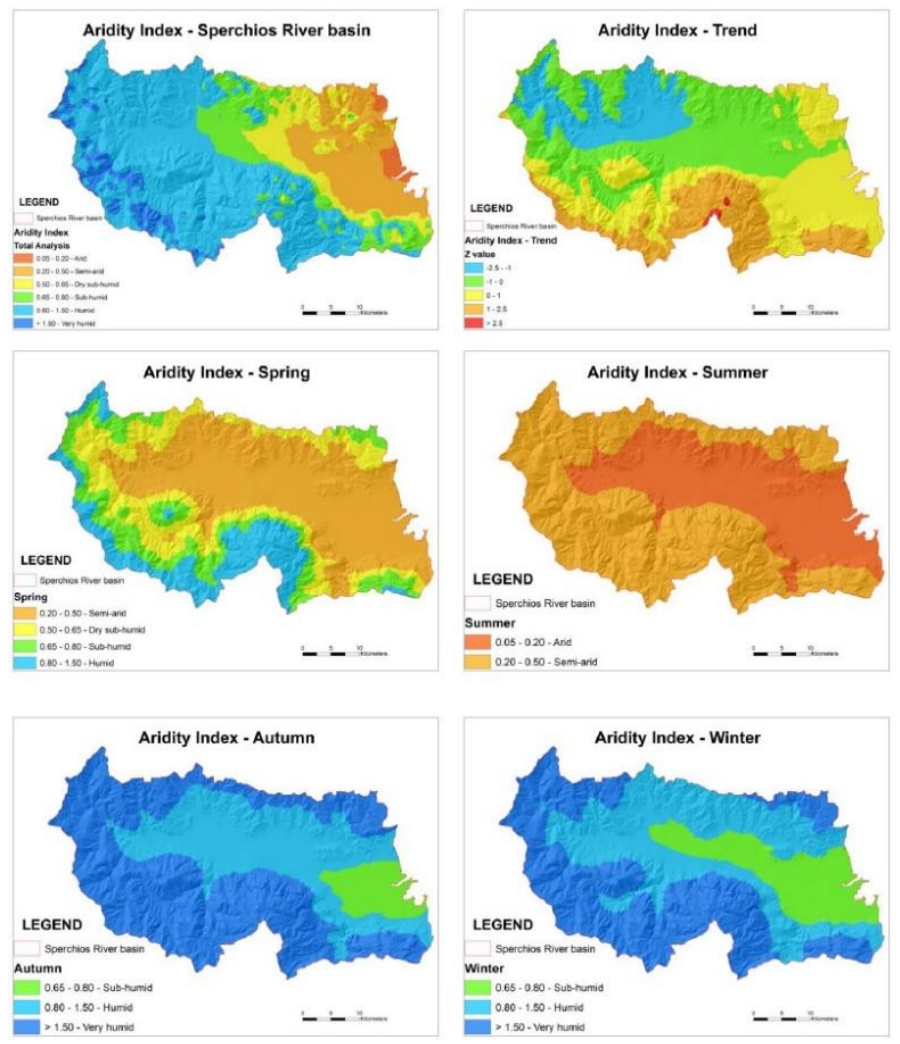

Figure 3. Aridity Index analysis maps for Sperchios River basin a) Total Analysis b) Trend c) Spring d) Summer e) Autumn f) Winter
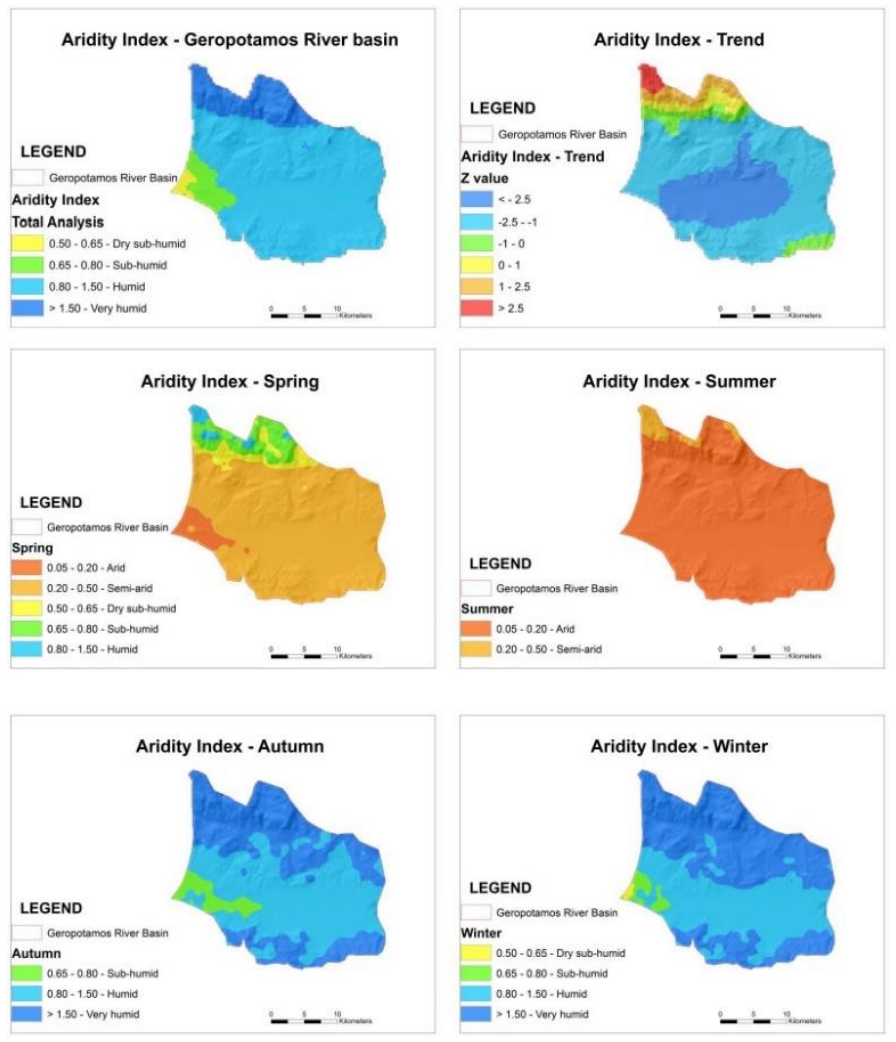

Figure 4. Aridity Index analysis maps for Geropotamos River basin a) Total Analysis b) Trend c) Spring d) Summer e) Autumn f) Winter 
Figure 2 depicts the aridity conditions analysis for the Ardas River basin. The analysis indicated that during the spatial interpolation of the $\mathrm{Al}$, the mountainous areas present humid conditions, while the areas with moderate altitude display drier conditions during the year. These areas are located mainly in the Greek part of the study area, where all the agriculture activity takes place. The map that depicts the fluctuation of Al for the spring season is the most characteristic in order to interpret the aridity conditions prevailing in Ardas River basin. According to the spatial interpolation of the Al for the spring season, four classes of Al classification exist with conditions ranging from humid (in the upper mountainous part of the basin) to semi-arid in the mouth of the basin.

Regarding the trend analysis of drought for the Ardas River basin, the lower parts present a very high downward trend while the mountainous west part of the basin where the sources of the Ardas River are located shows a mighty upward trend. This specificity tends to moderate the aridity conditions prevailing in the Ardas River basin within the next years. A factor that can behave as an inhibitor towards the appearance of drought conditions is the existence of large dams in the riverbed of Ardas. These dams can operate as adjusters respecting the water supply and demand, when flooding phenomena or drought conditions arise.

Respecting the Sperchios River basin, the results of the Al analysis according to Figure 3 indicated that the aridity conditions prevailing in the study area range from very humid in the upper areas of the basin, to arid near the coastline. In the areas where the main part of Sperchios valley lies, the conditions are semiarid. Seasonal Al mapping showed that during the spring and summer seasons the biggest part of the Sperchios valley faces semi-arid and arid conditions, respectively. These low values of Al especially on the certain seasons which constitute the main and the most critical face of the cultivation period point out the sententiousness of the issue and special attention needs to be given in order to avoid water scarcity problems that will have great impacts on the local population related with the agriculture activities. Differentiations during the spatial interpolation of the Al also appeared between the North and South part of the basin. The South part of the basin is characterized by high altitudes (as can be seen from Figure 1), while in the North part of the basin, moderate altitudes exist. This specificity affects the analysis as in Figure 3 the results in the southern part are more temperate compared with the northern part of the basin.

In Geropotamos River basin, according to the spatial interpolation of the Aridity Index that is presented in Figure 4, the largest part of the basin including the 'Messara' valley where all the agricultural activity takes place faces humid conditions. Some minor differentiations appear in the mouth of the Geropotamos River near the coastline where sub-humid or dry sub-humid conditions exist during the year. On the other hand, a prolonged part in the northern side of the basin where 'Psiloritis' Mount is located, presents very humid conditions. Seasonal analysis is affected by the topography of the area as in the North part where higher altitudes exist, the Al is presented with more temperate conditions, compared with the South part of the basin where the conditions are more severe and semi-arid or arid conditions appear for the spring and summer months following the Mediterranean climate conditions. Nonetheless, trend analysis showed that the part of the northern basin with the high altitudes tends to increase its drought conditions.

Generally, all the study areas showed an upward trend regarding the aridity conditions in the mountainous areas while the trend completely changes and follows a downward tendency in the lowland areas where all the agriculture activity takes place (plain areas). It is evident that elevation, as well as the geographic position, play a very important role in the creation of the climatic conditions prevailing in the results of the integrated analysis of aridity in the study areas. Furthermore, in locations with very abrupt slopes, the trend analysis indicated that the trend follows an upward intense tendency in all the study areas. A noteworthy fact is that during the trend analysis, all the study areas were presented with heterogenic trend although their size is characterized as medium. Additionally, another noticeable fact is the existence of large dams in Ardas and Geropotamos River basins that serve irrigation purposes. These dams can eliminate the difference between water supply and demand, especially in the summer months when the need for available water for irrigation is increased and the conditions are semi-arid or arid, as it was resulted from the current research. The water demand in the lower areas is higher than in other parts 
of the basin and it is apparent that if there is no rational management of the available water resources, drought conditions will occur and have great impacts on agriculture productivity.

Similar studies have been conducted in Greece and generally in the Mediterranean region towards the assessment of aridity conditions and several indicators and techniques have been proposed for the estimation and quantification of aridity. All these studies have used several statistical techniques to analyze spatio-temporal parameters of drought episodes and assess the conditions regarding the aridity (Nastos and Zerefos, 2009). Nastos et al., (2013) performed an application of the Aridity Index on a large scale for the whole Greek territory and Türkes (2003) for Turkey. The results of the above mentioned studies compared with the results from the current research, are similar, but it must be mentioned that these studies are different comparing to the current research. Specifically, the accurate estimation and mapping of aridity must take into account several factors. It is difficult to estimate the aridity conditions in a sizeable area such as Greece, which presents large and complex elevation variation, if less data is existing as inputs from the existing meteorological network. Additionally, in relation to all the above mentioned indices and studies, the technique for the estimation of PET that was followed in the current study that takes into account multiple variables as inputs $\left(R H, T_{\text {mean }}, T_{\text {max }}, T_{\min }, T_{\text {dew }}, R R, R_{s}, R_{n}, R_{a}\right.$, and WS) constitutes an innovation and validates that results of the current study compared with other similar studies and also highlights the fact that all future studies should be performed at least on a mesoscale, using sufficient inputs parameters, in order to produce reliable results.

PET plays a very important role in the current study. PET is mainly influenced by air temperature and solar radiation (Ampas, 2012). When hot conditions exist (especially during the summer months in areas with Mediterranean climate such as the Sperchios and the Geropotamos River basin), PET affects the fraction of the Aridity Index and results low values. During the winter season the exact opposite occurs. In the Ardas River basin where the climate is continental and the higher amounts of rainfall occur during the summer months, although PET has high values, the numerator of the fraction has also high values so aridity conditions are reduced. Same conditions occur during the winter season. At this latter case, however, there aren't very humid conditions as the levels of the winter precipitation are not so high.

Therefore the results of the Al are strongly influenced by the behaviour of PET. The results are confirmed as Crete Island during the data analysis appeared in many cases with almost zero rainfall from May to October. The use of a different index and method than this of the current research it would have gave extremely arid conditions in the Geropotamos River basin without taking into account various topographical and meteorological variables whose combination can serve as a regulator and prevent possible drought conditions.

The technique of spatial interpolation in the current study where a combination of the Ordinary Kriging method and multi-linear regression analysis were performed in order to take into account several coefficients also needs to be noticed. The initial default application of the method through ArcGIS 10.2.1 is performed without taking into account topographic, climatological and generally any additional data of the study area. Comprehending multi-linear regression that was performed in the current study, all the factors that affect each time the spatial interpolation were correlated.

During the multi-linear regression, in order to observe the statistical significance of the examined parameters, special attention was given in the output $p$-value. P-value indicates the probability of obtaining a test statistic result at least as extreme as the one that was actually observed, assuming that the null hypothesis is true (Pearson, 1900). P-value constitutes a great advantage during statistical analyses particularly for the complex terrain of Greece, in order to avoid significantly misleading conclusions, regarding e.g. arid Aegean Islands, etc.

Through the assessment of the aridity conditions, the emerge of drought conditions to appear is possible so the water resources planning and management must follow very careful steps. A general suggestion that can also be given is the creation of a dam in the mountainous areas of the Sperchios River basin, similar with the dams in the other study areas mentioned above, in order to act as a regulator and face possible drought conditions that are very likely to appear as it is inferred from the analysis of the current paper. Further research in the certain study areas needs to be performed in order for the researchers to 
understand the prevailing climate conditions and finally for an adequate meteorological network to be created; otherwise all research towards this direction will be governed by these deficiencies.

\section{Conclusions}

In the current research, the estimation of the Aridity Index for 3 areas widespread in Greece that face different climate conditions was conducted. Total analysis of aridity using the Aridity Index, seasonal analysis, trend analysis and finally mapping of the results was performed. Additionally, several procedures, techniques and software (multi-linear regression, ArcGIS, EmPEst) were combined in order to produce accurate estimations regarding aridity prevailing in areas with different climate conditions in Greece. Various maps were created, which visualize and give fundamental ideas and can constitute a helpful tool for the stakeholders in the study areas as these maps can be notified free of charge in the various stakeholders and understanding is possible for non-experts.

The results indicated that great caution is needed in making conclusions regarding the climate in the Mediterranean region. The climate of the Mediterranean region is one of the most vulnerable in terms of climate change with diverse social, economic and environmental impacts. The complex climatic conditions prevailing in both Greece and thus the Mediterranean region play a very important role in the creation of drought conditions, flooding phenomena, etc.

For this reason, all the upcoming studies need to focus on a mesoscale and local scale as it was performed in the current study; otherwise a large amount of input data is required in order to produce satisfactory results as well a combination of techniques, models and climate types that can often lead to overestimation or, even worse, to an underestimation of the events. Having in mind all these facts, in combination with all the recent findings in literature that have shown that the effects of climate change are significant, the researchers need to take crucial decisions regarding the sustainable management of the environment.

A future research could have been the assessment of the drought conditions or flooding phenomena prevailing in the certain study areas, and some future scenarios regarding their variability.

In any case, the findings of the current paper must be taken into account as a guide for future climate conditions. In order to avoid drought conditions or flooding phenomena the upcoming years, the science of mountainous water resources management in combination with hydrometeorology and climatology is called to play a major role in the era of climate change and should design and implement numerous technical and special projects, infrastructures, studies and research which today are more than ever necessary in order to prevail against the effects of climate change.

\section{Acknowledgments}

The input meteorological data were obtained from the Hellenic National Meteorological Service (HNMS). For the stations of Edirne (Turkish territory) and Kurdjali (Bulgarian territory) the data were obtained from www.ogimet.com.

\section{References}

Agnew C. and Anderson W. (1992), Water Resources in the arid realm, Routledge, London, U.K.

Allen R., Pereira L., Raes D. and Smith M. (1998), “Crop evapotranspiration - Guidelines for computing crop water requirements", Journal of Irrigation and Drainage Engineering, Paper 56, Rome: Food and Agriculture Organization (FAO), $300 \mathrm{p}$.

Ampas V. and Baltas E. (2012), Sensitivity analysis of different evapotranspiration methods using a new sensitivity coefficient, Global NEST Journal, 14(3), 335-343.

ASCE Task Committee on Standardization of Reference Evapotranspiration of the Environmental and Water Resources Institute (2005), The ASCE standardized reference evapotranspiration equation. Allen, R., Walter, I.A., Elliot, R.L., Howell, T.A., Itenfisu, D., Jensen, M.E., Snyder, R.L. (eds.), ASCE, Reston, VA, 172 p. 
Bleta A., Nastos P. and Matzarakis A. (2014), Assessment of bioclimatic conditions on Crete Island, Greece, Regional Environmental Change, 14, 1967-1981.

Caprio J. (1974), The solar thermal unit concept in problems related to plant development ant potential evapotranspiration. In: Lieth H (eds.) Phenology and seasonality modeling, Springer, New York, pp 353-364.

Chen C.C., Gillig D. and McCarl B.A. (2001), Effects of climatic change on a water dependent regional economy: a study of the Texas Edwards aquifer, Climate Change, 49(4), 397-409.

Dalezios N.R. and Bartzokas A. (1995), Daily precipitation variability in semiarid agricultural regions, Hydrological Sciences Journal, 40(5), 569-585.

Dalezios R.N., Loukas A., Vasiliades L. and Liakopoulos E. (2000), Severity-Duration-Frequency analysis of droughts and wet periods in Greece, Hydrological Sciences Journal, 45(5), 751-769.

De Martonne E. (1926), A new climate function: The Aridity index, La Meteorologie, 449-458 (in French).

Dingman S.L. (1994), Physical Hydrology, Macmillan Publishing Co., New York, NY.

Dingman S.L. (2002), Physical Hydrology, $2^{\text {nd }}$ ed., Prentice Hall, Upper Saddle River, NJ.

FAO (1993), Forest Resources Assessment 1990. Tropical Countries. Forestry Paper 112. Rome: Food and Agriculture Organization of the United Nations (FAO).

Feidas H., Karagiannidis A., Keppas S., Vaitis M., Kontos T., Zanis P., Melas D. and Anadranistakis E. (2014), Modeling and mapping temperature and precipitation climate data in Greece using topographical and geographical parameters, Theoretical and Applied Climatology, 118, 133-146.

Haan C.T. (2002), Statistical methods in Hydrology. $2^{\text {nd }}$ ed., lowa State University Press, Ames, lowa, 378pp.

Hillel D. and Rosenzweig C. (2002), Desertification in relation to climate variability and change, Advances in Agronomy, 77, 1-38.

Holman I.P. (2006), Climate change impacts on groundwater recharge uncertainty, shortcomings, and the way forward?, Hydrogeology Journal, 14(5), 637-647.

IPCC (2007), Contribution of Working Group 1 to the Fourth IPCC Assessment Report. In: Solomon S, Qin D, Manning M, Chen Z, Marquis M, Averyt KB, Tignor M, Miller HL, (ed) Climate Change 2007: The Physical Science Basis. Cambridge, UK: Cambridge University Press, $996 \mathrm{p}$

IPCC (2014), Climate Change 2014: Synthesis Report. An Assessment of Intergovernmental Panel on Climate Change. Geneva Switzerland, http://ipcc.ch/index/html

Irmak S., Allen R. and Whitty E. (2003), Daily grass and alfalfareference evapotranspiration estimates and alfalfa-tograss evapotranspiration ratios in Florida, Journal of Irrigation and Drainage Engineering, 129(5), 360-370.

Jacobs J.M. and Satti S.R. (2001), Evaluation of reference evapotranspiration methodologies and AFSIRS crop water use simulation model, Final Rep., St. Johns River Water Management District, Palatka, FL.

Jensen M. and Haise H. (1963), Estimating evapotranspiration from solar radiation, Journal of Irrigation and Drainage Engineering, 89, 15-41.

Kendall M.G. (1938), “A new measure of rank correlation.” Biometrika, 30, 81-93.

Kendall, M. G., and Stuart, A. (1969), The Advanced Theory of Statistics. vol. 1, $3^{\text {rd }}$ Ed., Hafner, New York.

Kendall, M. G. (1975), Rank Correlation Methods. Charles Griffin, London, UK.

Kostinakis K., Xystrakis F., Theodoropoulos K., Stathis D., Eleftheriadou E. and Matzarakis A. (2011), Estimation of reference potential evapotranspiration with focus on vegetation science - the EmPEst software, Journal of Irrigation and Drainage Engineering, 137, 616-619.

Lu J., Sun G., McNulty S. and Amatya D. (2005), A comparison of six potential evapotranspiration methods for regional use in the southeastern United States, American Water Resources Association, 41(3), 621-633.

Maliva R.G. and Missimer T.M. (2012), Arid Lands Water Evaluation and Management, Springer-Verlag Berlin Heidelberg, p. 1076.

Mann H.B. (1945), Nonparametric tests against trend, Econometrica, 13, 245-259.

Manolas E., Tampakis S., Gkaintatzis S. and Mavridou-Mavroudi S. (2009), Recreation in the area of River Ardas: The views of Elementary school pupils, Tourismos: An International Multidisciplinary Journal of Tourism, 5(2), 99-114. 
Maris F., Kitikidou K., Angelidis P. and Potouridis S. (2013), Kriging Interpolation Method for Estimation of Continuous Spatial Distribution of Precipitation in Cyprus, British Journal of Applied Science \& Technology, 3(4), 1286-1300.

Matzarakis A. and Nastos P. (2011), Analysis of tourism potential for Crete Island, Greece, Global NEST Journal, 13(2), 141-149.

Matzarakis A., Ivanova D., Balafoutis C. and Makrogiannis T. (2007), Climatology of growing degree days in Greece, Climate Research, 34, 233-240.

Oliver M.A. and Webster R. (1990), Kriging: a method of interpolation for geographical information systems, International Journal of Geographical Information Systems, 4(3), 313-332.

Oudin L., Hervieu F., Michel C., Perrin C., Andréassian V., Anctil F. and Loumagne C. (2005), Which potential evapotranspiration input for a lumped rainfall-runoff model? Part 2 - Towards a simple and efficient potential evapotranspiration model for rainfall-runoff modeling, Journal of Hydrology, 303(1), 290-306.

Nastos P. and Zerefos C. (2009), Spatial and temporal variability of consecutive dry and wet days in Greece, Atmospheric Research, 94, 616-628.

Nastos P., Politi N. and Kapsomenakis J. (2013), Spatial and temporal variability of the Aridity Index in Greece, Atmospheric Research, 119, 140-152.

Paparrizos S., Maris F. and Matzarakis A. (2014), Estimation and Comparison of Potential Evapotranspiration based on daily and monthly data from Sperchios River valley in Central Greece, Global NEST Journal, 16(2), 204-217.

Paparrizos S. and Maris F. (2015a), Hydrological simulation of Sperchios River basin in Central Greece using the MIKE SHE model and Geographic Information Systems, Applied Water Science, doi: 10.1007/s13201-015-0271-5 (In press).

Paparrizos S., Maris F. and Matzarakis A. (2015b), Mapping of drought for Sperchios River basin in Greece, Hydrological Sciences Journal, (in press) http://dx.doi.org/10.1080/02626667.2014.965175.

Paparrizos S., Maris F. and Matzarakis A. (2016), Integrated analysis of present and future responses of precipitation over selected Greek areas with different climate conditions, Atmospheric Research, 169, 199-208.

Pearson K. (1900), Mathematical contributions to the theory of evolution, VII: On the correlation of characters not quantitatively measurable, Philosophical Transactions of the Royal Society of London, A195, 1-147.

Peel. M.C., Finlayson B.L. and McMahon T.A. (2007), “Updated world map of the Köppen-Geiger climate classification, Hydrology and Earth Systems Sciences, 11, 1633-1644.

Rosenberry D.O., Stannard D.I., Winter T.C. and Martinez M. L. (2004), Comparison of 13 equations for determining evapotranspiration from a prairie wetland, Cottonwood Lake Area, North Dakota, USA, Wetlands Ecology and Management, 24(3), 483-497.

Salmi T., Määttä A., Anttila P., Ruoho-Airola T. and Amnell T. (2002), Detecting trends of annual values of atmospheric pollutants by the Mann-Kendall test and Sen's slope estimates - the Excel template application MAKESENS. Publications on air quality, Finnish Meteorological Institute, Air Quality Research, No. 31, Helsinki, Finland.

Saravi M., Safdari A. and Malekian A. (2009), Intensity-Duration-Frequency and spatial analysis of droughts using the Standardized Precipitation Index, Hydrology and Earth System Sciences Discussions, 6, 1347-1383.

Sheffield J., Andreadis K., Wood E. and Lettenmaier D. (2009), Global and continental drought in the second half of the twentieth century: Severity-area-duration analysis and temporal variability of large-scale events, Journal of Climatology, 22, 1962-1981.

Snedecor G.W. and Cochran G. (1989), Statistical methods, $8^{\text {th }}$ ed. lowa State University, Ames, lowa, 803 pp.

Stobbelaar D.J., Kuiper J., Van Mansvelt J. and Kabourakis E. (2000), Landscape quality on Organic farms as components in the landscape, Agriculture Ecosystems and Environment, 77, 79-93.

Thornthwaite C.W. (1948), An approach toward a rational classification of climate, Geographical Review, 38(1), 55-94.

Tigkas D., Vangelis H., and Tsakiris G. (2012), Drought and climatic change impact on streamflow in small watersheds, Science of the Total Environment, 440, 33-41.

Türkes M. (2003), Spatial and temporal variations in precipitation and aridity index series in Turkey. In: Bölle H-J (eds.) Mediterranean climate. Variability and trends. Springer, pp 181-213.

United Nations Environment Programme (UNEP) (1992), World Atlas of Desertification. Edward Arnold, London, UK. 
Wang G. (2005), Agricultural drought in a future climate: results from 15 global climate models participating in the IPCC 4th assessment, Climate Dynamics, 25(7-8), 739-753.

Wang G., Minnis R.B., Belant J.L. and Wax C.L. (2010), Dry weather induces outbreaks of human West Nile virus infections, BMC Infectious Disease Journal, 10(38), 1-7.

Xu C.Y. and Singh V.P. (2002), Cross comparison of empirical equations for calculating potential evapotranspiration with data from Switzerland, Water Resources Management, 16(3), 197-219.

Xystrakis F. and Kostinakis K. (2010), EmPEst - empirical reference potential evaporation estimation: user's guide. Available at http://empest.wordpress.com/

Xystrakis F. and Matzarakis A. (2011), Evaluation of 13 empirical reference potential evapotranspiration equations on the island of Crete in southern Greece, Journal of Irrigation and Drainage Engineering, 137, 211-222.

Zampakas J. (1992), General Climatology. Department of Geology, National \& Kapodistrian University of Athens, Athens, Greece. 